\title{
A “Brazilian Way"? Brazil’s Approach to Peacebuilding
}

\section{Adriana Erthal Abdenur and Charles T. Call}

\section{INTRODUCTION}

Since the early 2000s, Brazil has been a high-profile advocate of nonWestern approaches to development cooperation, peace operations, and other initiatives related to peacebuilding. This avid support is associated primarily with the administration of President Lula Inácio da Silva (2003-2010). During this period, Brazil sought greater prominence on the international stage on several fronts. Brazil pressed for transformations in the multilateral system, including helping to create and then exercise leadership in fora such as the BRICS (Brazil, Russia, India, China, and South Africa) coalition and the IBSA (India, Brazil, and South Africa)

Adriana Erthal Abdenur is grateful to the Brazilian Council for Scientific and Technological Development (CNPq) and its Senior Postdoctoral Scholarship program for supporting this research through the Centro de Pesquisa e Documentação de História Contemporânea do Brasil (CPDOC) at Fundação Getúlio Vargas in Rio de Janeiro.

A.E. Abdenur $(\bowtie)$

Fundação Getúlio Vargas, Rio de Janeiro, Brazil

C.T. Call

School of International Service, American University, Washington, DC, USA

(C) The Author(s) 2017

C.T. Call, C. de Coning (eds.), Rising Powers and

Peacebuilding, Rethinking Peace and Conflict Studies,

DOI 10.1007/978-3-319-60621-7_2 
Dialogue Forum. It also worked to gain greater influence within the multilateral system, boosting its historic bid for a permanent seat on the UN Security Council and contesting United Nations (UN) securitization. Under Lula, Brazil almost tripled its development cooperation to \$1.6 billion reais (USD $\$ 923$ million at the time). Some $66.3 \%$ of this total was channeled through multilateral cooperation, and the remainder with bilateral efforts focusing on Latin America and Africa (IPEA 2011). This represented a significant surge and diversification in Brazil's role in development, including in many conflict-affected countries.

More broadly, during this period Brazil became more active in a variety of initiatives that can be considered to fall under the concept of peacebuilding. As part of its South-South development cooperation efforts, Brazil vastly expanded its technical cooperation with post-conflict countries such as Angola, Mozambique, Guinea-Bissau, and East Timor. It also sponsored and executed peace-related development projects to support the UN Stabilization Mission in Haiti (MINUSTAH), whose military command it held continuously for an unprecedented 12 years, starting in 2004. Both in its home region and beyond this vicinity, Brazil engaged in conflict mediation efforts, whether through regional organizations like the Union of South American States (UNASUR) or via ad hoc arrangements. At the UN, Brazil was instrumental in the creation of the UN Peacebuilding Architecture, and once established it assumed a broader leadership role at the Peacebuilding Commission, especially with respect to Guinea-Bissau. In UN normative debates, Brazil promoted peacebuilding as a complement and sometimes as an alternative to militarized approaches to peacekeeping, arguing that investing in political processes and socioeconomic development was essential to the promotion of peace.

This chapter describes the scope of, and trends in, Brazil's peacebuilding activities since the early 2000 s, focusing on the eight-year Lula presidency and, to a lesser extent, its aftermath. It analyzes the broader context, key principles, and main mechanisms of Brazilian peacebuilding; identifies major patterns and trends; and notes some of the most important challenges and contradictions. In particular, we examine whether there is a "Brazilian" approach to peacebuilding and what its elements might be, as well as how that approach differs from dominant or Western principles and practices. The research is based on interviews conducted in mid-2015 and mid-2016 in Brasilia, Rio de Janeiro, and New York, as well as analysis of official documents from the UN and the Brazilian government.

We find that, although Brazilian stakeholders rarely use the term "peacebuilding" (in Portuguese, "consolidação da paz") outside UN 
debates, and while there is no single dedicated government agency guiding this engagement (and rather, a broad gamut of institutions whose efforts include peacebuilding activities), Brazilian efforts abroad constitute a loose but emergent approach to promoting stability and development in partner countries. Brazil has articulated clear principles of a peacebuilding approach that differs in policy and on-the-ground practice from those of Western donors. Nevertheless, Brazil's approach also shares some similarities with Western peacebuilding, both normatively and operationally. In the post-Lula years, two main elements-the economic downturn in Brazil and the political turmoil surrounding Rousseff's presidential impeachment-has reoriented Brazilian foreign policy, raising new questions about Brazil's ability to sustain its emerging role in peacebuilding.

\section{Foundations of a Brazilian Approach to Peacebuilding}

Brazil has no single document, such as a White Paper, outlining a policy framework for peacebuilding. The term consolidação da paz, in fact, is seldom used outside multilateral settings such as the UN and IBSA. Outside of those platforms, Brazil's approach to peacebuilding can be inferred from official speeches and statements, national security documents, diplomats' understandings, and actions along three fronts: development cooperation, international conflict mediation, and humanitarian assistance.

Despite the breadth of these initiatives, certain common principles underlie Brazil's approach to peacebuilding, and these concepts are frequently evoked by Brazilian diplomats and some academics in arguing that there is a distinct "Brazilian" approach to promoting peace and stability. While Brazilian officials and experts do not exclude the possibility that other countries embrace or reflect similar principles, they often defend the idea that these principles are based on Brazil's somewhat unique historical trajectories and experiences with peace and development, and that, as a result, Brazil's engagement with peacebuilding entails more equitable relations of power among stakeholders.

\section{Historical Foundations}

Although most initiatives that make up Brazil's peacebuilding have emerged in the past 15 years, the country's historical trajectory offers a source of inspiration for its current approach. Relevant here are (a) Brazil's status as a colony of Portugal that "shrugged off" empire and assumed 
independence with minimal violence; (b) its legacy as the largest slave importing state in the Americas, as well as the last nation in the Western world to abolish the practice; and (c) its position as a regional power that nurtures ambitions to become a global power yet remains sensitive to how its exercise of power in the hemisphere is perceived by its neighbors.

As a result of its own colonial experience, as well as its sheer size (Brazil is now the world's fifth largest country by territory and accounts for $48 \%$ of South America's territory), Brazil has repeatedly sought to reassure other countries in its vicinity that it would not abuse its vast geography to seek regional hegemony. According to the mainstream historiography, upon independence, in 1822, within its relations with other states Brazil adopted a "culture of pacifism" meant to prevent the newly formed sovereign country from being seen as imposing or intruding on its neighbors. ${ }^{1}$ The 1934 constitution - which only lasted three years but was extremely influential in the drafting of subsequent constitutions-states that Brazil will "never engage in a war of conquest" and stipulates that war shall not be launched until arbitration is exhausted (Constituicao 1934). Similarly, textbooks stress the country's non-military approaches to foreign engagement-leitmotifs that have carried into contemporary discourses of foreign policy. ${ }^{2}$ There were some early territorial wars against neighboring countries, especially over the Cisplatine province (which became, with British mediation, independent Uruguay in 1928), and coercive diplomacy was used with Bolivia and Argentina during territorial disputes. Internally, there were a handful of revolts in the Southern and Northern regions (including the Canudos War, a popular-messianic uprising that was crushed by the Brazilian Army in 1897). Despite these incidents, the country managed to avoid major interstate conflicts and, as a result, the country's pacifist mythology emphasizes that Brazil has never launched a war. $^{3}$

Despite its relatively peaceful trajectory in defining its borders, and although the country's population is historically diverse, Brazil has a far less harmonious history when it comes to issues of ethnicity and race. The formation of Brazil as a people was the result of violent processes (Ribeiro 1995). The colonial state exterminated and marginalized indigenous people and, even after the formal end of slavery, its "whitening" immigration policies favored Europeans. Over a century of institutional denial of racial and ethnic differences has led to unacknowledged deep inequalities and discrimination that are most visible in the country's contemporary high rates of violence (a 2013 UNODC study showed that Brazil had 25.2 homicides per 1,00,000 people, among the highest in the world) 
(UNODC 2013). As a result, despite its official discourse of pacifism and harmony, Brazil's internal contradictions sometimes belie the rhetoric of peace and stability that officials and others draw upon in legitimizing Brazil's role in peacebuilding. The same can be said of the country's turbulent history with democracy, with several periods of repressive military regime (including from 1964 to 1985) and a political trajectory marred by presidential coups and countercoups.

\section{The Post-World War II Period}

During the Cold War, and especially when the country was under military rule, Brazilian foreign policy largely aligned with that of the USA, even as Brazil retained its membership in the G77 and was among the most active states fighting for the inception of the UN Conference on Trade and Development (UNCTAD). Although Brazil has never been a member of Non-Aligned Movement (NAM), it has followed many of the group's initiatives as an observer, and there are strong parallels in Brazil's discourse of solidarity and that of the movement. This ambivalence in Brazilian foreign policy toward the rest of the developing world-and its resulting policy shifts—also characterized Brazil's stance toward the struggle against colonialism in the mid-twentieth century. As Portugal's empire was collapsing in the early 1970s, Brazil-which previously had mostly stood by Portugal's position against the independence of African states in UN debates-began supporting decolonization in Angola, Mozambique, and other Lusophone colonies (Pinheiro 2007). Thereafter, Brazil's foreign policy placed an even stronger emphasis on non-intervention and peaceful approaches to resolving conflict.

Outside of its immediate vicinity, Brazil engaged in issues of international security by becoming an early contributor to UN peacekeeping missions, starting with the first mission (UNEF I, in Sinai) in 1956. This participation launched a long-term commitment to UN peacekeeping, although troop contributions have varied over time; to date, Brazil has participated in more than 50 peacekeeping operations and related missions, having contributed over 33,000 military officials, police officers, and civilians (Brazilian Ministry of Foreign Affairs). This participation reflects Brazilian foreign policy's longstanding commitment to multilateralism, particularly via the UN.

Toward the end of the Cold War, even as Brazil underwent a gradual transition from military to civilian rule, it worked with Argentina to overcome a deep historical rivalry that had culminated in both countries 
attempting to develop nuclear weapons. The two sides successfully resolved their tensions by deepening political and economic ties (for instance, via Mercosur) and voluntarily dismantling their nuclear weapons programs, while maintaining their peaceful elements. The 1991 establishment of the Brazilian-Argentine Agency for Accounting and Control of Nuclear Materials (ABACC), a bilateral safeguards agency, marked an innovative way of institutionalizing peaceful conflict resolution between the two states and avoiding regional tensions (de Quieroz 2016). The resulting warming of ties between the two countries is often cited by Brazilian diplomats as a way of boosting Brazil's credentials in conflict prevention and resolution (Patriota and Timerman 2011).

\section{The Post-Cold War Period}

With the end of the Cold War, Brazil relied even more heavily on multilateral platforms to expand its role in international peace and security, not only through the UN but also via regional platforms such as Mercosur and, more recently, UNASUR, which was created in 2008. Especially in Africa, Brazil has been active in peacebuilding through the Community of Portuguese-Language Countries (CPLP). And, since the 2000s, it helped to create new coalitions of rising powers, such as IBSA and the BRICS. Working through multilateral institutions not only provides Brazil with added legitimacy in peacebuilding, it also helps to extend its reach geographically, since other members sometimes engage in peacebuilding efforts in countries where Brazil's bilateral relations are relatively weak.

This predilection for multilateralism has been essential to understanding Brazilian efforts to promote democracy and human rights abroad. Brazil has historically eschewed direct engagement in promotion of democracy and human rights in other countries because this practice is sometimes associated with Western powers' self-interested and selective efforts, which have often yielded counterproductive outcomes. However, Brazil engages in democracy and human rights promotion when a specific demand arises via a multilateral forum, including the Organization of American States (OAS), UNASUR, and the CPLP.

Brazil has, on occasion, tried to boost its role in mediation of conflicts in South America. In 1995, it worked with the USA, Chile, and Argentina to mediate the brief border conflict between Peru and Ecuador, the Cenepa War (Biato 1999). The ensuing 1998 peace agreement, the Brasília Presidential Act, was definitive in establishing the formal demarcation of 
the border, putting an end to one of the longest territorial disputes in the Western Hemisphere. Despite these examples, Brazil's engagement in conflict mediation within its own region has remained sporadic and selective.

\section{The Core Principles of Brazilian Peacebuilding}

The early 2000s witnessed a new, concerted effort by Brazil to engage on peacebuilding issues. The figure of Lula was central to this surge. A former factory worker and union leader who was imprisoned briefly by the military dictatorship, Lula led the socialist Workers Party for 14 years through the country's transition from authoritarianism. Elected based on a coalition representing urban workers, peasants, and the lower middle classes, Lula sought to transform Brazil into a more equitable society while using foreign policy to boost development and expand the country's influence abroad, including in international security issues.

In foreign policy, Lula's government frequently drew on domestic policy initiatives as inspirations to combat poverty and hunger globally. To this end, the Brazilian government promoted a discourse of solidarity and horizontality, presenting its South-South development cooperation efforts as devoid of the power asymmetries resulting from Europe and the USA's colonial and imperial legacies in much of the developing world. In 2013, the director of ABC [a Brazilian Cooperation Agency, a division of the Ministry for External Relations (MRE)] underscored the principles believed to differentiate Brazil's approach from those of donors and established multilateral organizations:

The policy of Brazilian cooperation is based on international solidarity $[\ldots]$ we react to the demands (we don't have previously prepared projects to be presented to partners). [...]The principle of South-South cooperation that we follow is that of no conditionality, which is the non-linkage between technical cooperation and pursuit of economic and commercial goals and benefits or concessions in areas of services in exchange for cooperation. [Another principle Brazil respects is the] non-interference or nonintromission in internal affairs. (de Abreu 2013)

These principles-solidarity, demand-driven cooperation, nonconditionality, and non-interference-are invoked by Brazilian diplomats as the hallmarks of a distinct "Brazilian way." In addition, the Lula 
administration emphasized national ownership of development cooperation projects abroad as part of the country's respect for sovereignty. However, some have criticized Brazil's solidarity as strictly targeting other governments (regardless of type of regime) and of equating "national" ownership with "government" decision-making, as opposed to more participatory processes that would include non-governmental and opposition voices in partner states (Abdenur and Marcondes 2016). Other traits of what might be termed a "Brazilian way" include Brazilians' proclivity for closeness to people in local communities abroad (a point that is often stressed with respect to Brazilian peacekeepers), emphasis on economic programs and job generation in post-conflict countries, and reliance on development cooperation rather than on aid.

Some of these principles resonated with, and were in turn reinforced by, Lula's initiatives in global coalition-building, especially with other rising powers. The creation of coalitions like IBSA, which brings together three diverse democracies, and the BRIC (which in 2011 expanded to include South Africa and became known as BRICS), reflected both a desire to transform the international system into a more multilateral configuration and an aspiration to open up more space for Brazil's own possibilities abroad. The BRICS adopted a highly contestatory discourse vis-à-vis certain components and norms of the established global governance architecture, and began to deepen cooperation and coordinate some positions, especially on issues related to economic cooperation and development financing. The coalition acquired a greater degree of institutionalization by launching new institutions, such as the BRICS New Development Bank (NDB) (BRICS 2014). The NDB is meant not only to help fill the gargantuan demand for infrastructure financing in the developing world, but also to place further pressure on established institutions like the Bretton Woods organizations to undertake serious reform in their decision-making processes. The new institution is relevant to peacebuilding because, at a normative level, the bank reinserts infrastructure investment at the heart of development debates, including within conflict-affected areas.

Despite its visibility, the BRICS and IBSA are not the only informal coalitions on Brazil's rising power agenda. The G20, initially launched in 1999 , became more important to Brazilian foreign policy in the 2000s as a high table for global governance and economic policy. On a far lesser scale, Brazil also helped to establish and expand bi-regional summits such as the Summit of South American-Arab Countries and the Africa-South America Summit. Brazil's role in these various informal coalitions of states, 
which helped to expand its influence across the Global South, was decisive and influential for its peacebuilding initiatives in part because they granted Brazil greater legitimacy in engaging in a wider variety of contexts.

Within the UN System, this contestatory tone translated into demands for organizational reforms, including changes to the Security Council that would guarantee Brazil a permanent, veto-wielding seat on the UN Security Council. In this respect, Brazil has sought alignments beyond rising powers. For instance, starting in the mid-2000s, the country joined Germany, Japan, and India in the G-4, whose members seek a more democratic Council that would reflect contemporary interstate relations rather than the aftermath of World War II (Brazilian Ministry of Foreign Affairs). Although these countries helped prompt the formation of a High-Level Panel on UN Reform in 2004, its recommendations for broadening the Council's membership were not acted upon. As a Brazilian diplomat in Brasília put it, "This failure to reform added to the palpable sense of frustration among [us], thus strengthening the resolve to launch alternative routes outside the UN architecture, especially through the loose coalitions of rising powers." 5

Nevertheless, at the UN Brazil engaged more directly in key normative debates about security and development. At the UN Security Council, where Brazil occupied a non-permanent seat in 2004-2005 and in 2010-2011 (making it, along with Japan, the member state that has occupied such a position the most times in UN history), (Ministry of Foreign Affairs) Brazil argued that the UN has neglected its original focus on conflict prevention and post-conflict reconstruction in favor of heavyhanded military interventionism, whether led by North Atlantic Treaty Organization (NATO) or otherwise. As one Brazilian diplomat states,

In general terms the UN has focused too much on the pillar of peace and security versus development. Decisions have been toward militarized solutions.... In our view, peacekeeping and peacebuilding shouldn't be sequenced, but should be dealt with together, in tandem. When dealing with a post-conflict situation, one must deal with the causes of the conflictinstitutional, political, social and environmental. (Patriota 2011)

These sentiments reflect the foreign policy principles encoded in the 1988 federal constitution, such as non-intervention, self-determination, international cooperation, and the peaceful settlement of conflictsprinciples that had long guided Brazil's positions at the UN. Back in the 
early 1990s, for instance, Brazil proposed that the UN Secretariat produce an "Agenda for Development" to complement the influential "Agenda for Peace" published by Boutros Boutros-Ghali in 1992 (Vigevani and Cepaluni 2012). However, under Lula Brazil placed greater emphasis on the transformative agenda. When chairing the Security Council in 2011, Brazil chose to focus a debate on "security and development." Brazil emphasized the interconnectedness of these aims as reflected in the presidential statement (PRST) that the Security Council adopted: "The Security Council underlines that security and development are closely interlinked and mutually reinforcing and key to attaining sustainable peace" (President of UN Security Council 2011). The statement also recognized and called for strengthening the links between peacekeeping and early peacebuilding.

One Brazilian diplomat reflected on Brazil's efforts:

I see that [PRST] statement as the culmination and heyday of a process of thinking about peacekeeping and peacebuilding in Brazil. From 2002 to 2011, we were learning how to be norm-setters in the international community. Haiti was formative in conceptual development but also in the coalition-building element. We learned how to twist arms to have our concepts included in the Council's resolutions. ${ }^{6}$

Similarly, Brazil's 2012 attempt to temper the principle of Responsibility to Protect (R2P) by proposing the concept of Responsibility while Protecting ( RwP) - despite never gained significant traction-demonstrates Brazil's occasional willingness to make high-profile proposals for alternatives to Western approaches. It also shows that Brazil's primary platform for engaging with international security and peacebuilding, at least at a normative level, remains the UN. We now turn to how these broader concepts and principles play out in practice in Brazil's peacebuilding efforts.

\section{Brazil's Peacebuilding in Practice}

\section{UN Peace Missions}

When Brazil assumed the leadership of the military component of MINUSTAH, in 2004, the move represented a significant step up in its commitments to UN peacekeeping. That engagement became even more 
complex after the 2010 earthquake created a humanitarian crisis superimposed on an already highly unstable setting. Even before the disaster, Brazil was the single largest troop contributor country to MINUSTAH, as well as a part of the core group of countries in Port-au-Prince and in the "Group of Friends of Haiti" in New York. Brazil saw the Haiti mission as a chance to initiate an alternative approach to UN peacekeeping-in essence, a more peacebuilding-oriented approach. As one Brazilian diplomat said, "This was key in Haiti: how do we make it different? Our assessment was that the US effort in the 1990s was a failure because it invested too much in the military and not enough in development and capacities."

Brazil pressed for authorization to use UN peacekeeping funds, generally restricted to funding peacekeepers and their operational needs, on development and peacebuilding-oriented programs in Haiti. As another diplomat reported, "In the Security Council and in the fifth [budget] committee, we pushed for quick-impact projects [QIPs] and community violence programs for Haiti." The UN allocated approximately USD \$5 million annually to these QIPs (Ministry of Foreign Affairs). In one example that combined elements of development and peacebuilding, the "Light and Security" initiative, coordinated by Brazilian troops, installed solar lampposts in the most vulnerable parts of the capital, making those areas safer at night (UN Brazil 2013).

The Brazilian Corps of Engineers also helped to perforate wells, build bridges and dams, and carried out slope stabilization in landslide-prone areas (Ministry of Foreign Affairs 2014). One Brazilian diplomat reported that, in Haiti, "Our military engineers pushed the boundaries. The UN Secretariat wouldn't let us repair roads too far from the battalion base [i.e., not required for MINUSTAH operational needs], so we brought in our own asphalt manufacturing capability and used Embassy funds to pay for road repairs elsewhere." In many of these initiatives, Brazilian troops built upon the development-oriented activities that the Brazilian Armed Forces carry out domestically, for instance in remote areas of the Amazon and border regions.

In a somewhat usual arrangement, in Haiti the Brazilian government also created a partnership with Viva Rio, a Rio-based NGO that had specialized in community peacebuilding and disarmament in urban Brazil, to carry out humanitarian and development initiatives in areas of Haiti that had been strongly affected by the earthquake and ensuing crisis. For instance, Viva Rio coordinated a reconciliation program in which it helped mediate between the Haitian national police and leaderships from 
different parts of Bel Air, Cité Soleil and Delmas. Viva Rio also received MINUSTAH financing to carry out sports (including capoeira) and culture (such as Carnaval celebrations) in strengthening this mediation initiative (Viva Rio 2015). At the same time, the Brazilian government provided bilateral technical cooperation in social policy areas like public health, agriculture, energy, and capacity-building. Through these different arrangements, Brazil worked to complement the military role in MINUSTAH with initiatives that would promote social well-being and stability in the long term.

Brazilian diplomats and analysts identify specific differences in the country's approach to peacekeeping that have led some to refer to the "Brazilian way." First among these is the warm conviviality of Brazilian culture, including the open and friendly manner of its soldiers in dealing with the Haitian population. Many Brazilian solders come from the poor favelas and communities that share traits with the most difficult communities in Haiti, and many are similarly dark-skinned, despite Brazil's complicated race relations. Related to this cultural affinity was Brazil's early decision to deploy its forces with greater contact and proximity to the populations, especially in shantytown communities like Bellaire and Cité Soleil considered to have been taken over by politicized criminal gangs opposed to the government. One analyst described a decision that, when Brazil's troops entered Bellaire in 2006, they would remove their sunglasses, look into the eyes of the people, and-in contrast to the Jordanian units-get out of their armored personnel carriers (APCs) and walk in the streets and converse with the population. ${ }^{9}$ In addition, Brazilian forces announced their entry into the community a few days prior, letting the criminal gang leaders leave and granting Brazilian troops non-confrontational entry and continued presence in these communities. Brazil followed up these operations with social programs. Numerous analysts have evaluated and documented the more positive reaction of the inhabitants of these communities to the Brazilian units over earlier troops.

Brazil's approach in Haiti, including in Bellaire, was neither uniform nor unproblematic. Despite the discourse on Brazilian conviviality and ease in integrating with locals, its participation in MINUSTAH has not been without critics. Some note that there is a feedback loop between Brazilian security forces' heavy-handed presence in (or incursions into) the favelas in Rio and the peacekeeper's approach to urban gangs in Haiti (Muller 2016). Certain Brazilian observers have criticized the insufficient coordination among stakeholders in Haiti, including Brazil (Hirst 2010). 
Others have also noted that, as a result of its Haiti's engagement, Brazil's approach to peacebuilding often relies on a heavy military component and an uneasy or incomplete relationship with both Brazilian and local civil society actors. The same can be said of Brazil's humanitarian efforts, in which Brazilian civil society and its official engagement with local nongovernment actors is minimal, if at all present.

Aside from Haiti and East Timor, most conflict-affected countries that Brazil has engaged with lie in Africa (Santos and Cravo 2014). During the 2000s, in particular, Brazilian peacebuilding initiatives expanded on the continent as part of Lula's broader drive to increase Brazil's presence in, and relevance to, Africa, especially the Sub-Saharan countries. Lula engaged in a highly visible presidential diplomacy, making 33 countryvisits to partner states in the continent. He opened 19 embassies in the continent. His speeches tended to underscore the idea of solidarity and kinship, stressing that Brazil had a moral debt to Africa due to the heavy influence of African slavery on Brazilian society.

\section{Development Cooperation}

In its efforts to expand Brazilian cooperation with partner nations, the Lula government significantly broadened technical expert cooperation, especially in Africa and Latin America, with a focus on social policy areas such as tropical agriculture, public education and public health. During the eight years of his two-mandate presidency, Lula visited 27 African countries, opening and reopening embassies around the continent (Peixoto 2010). Brazil's expanded development and peacebuilding efforts reflected not just ideological commitments to South-South solidarity, but also a pragmatic recognition that Brazil's ambitions to transform global power would require the political support of many countries of the global South.

Brazil branded itself a policy innovator in policy areas like public health, education, and tropical agriculture, framing its own development experiences as more similar to those of partner countries than those of traditional donors. Most of this technical cooperation is coordinated by the Brazilian cooperation agency (ABC), a division of the Ministry for External Relations (MRE). The ABC's annual budget grew from 18.7 million reais in 2006 to 52.26 million in 2010, the last year of Lula's second mandate (Ministry of Foreign Affairs). In 2009 alone, half the budget was spent in African countries, while 23\% was spent in South America, 12\% in Central America and the Caribbean, and 15\% in Asia-illustrating 
that Brazil's technical cooperation portfolio was not driven entirely by regional considerations (Ministry of Foreign Affairs).

The ABC coordinates works with the implementing institutions (mostly other ministries or associated institutions, such as Fiocruz, the public health institution attached to the Ministry of Health, and Embrapa, the public agriculture research and development company affiliated with the Ministry of Agriculture. Less frequently, $\mathrm{ABC}$ partners with non-governmental institutions like SENAI (National Service for Industrial Learning) to carry out vocational and professional education programs abroad, but local civil society entities are rarely directly involved in Brazil's technical cooperation initiatives. Although Brazil still lacks a legal framework for regulating its international development cooperation (or humanitarian assistance, examined below), its project portfolio diversified considerably during Lula's two mandates, both geographically and thematically. It also came to incorporate more trilateral cooperation arrangements, whether with donor states [for instance, Japanese International Cooperation Agency (JICA)] or with multilateral platforms like the European Union or IBSA (Brazilian agency for cooperation, Ministry of Foreign Affairs).

The majority of cooperation projects involve sending Brazil-based experts from those institutions on short missions abroad to share knowledge and experiences with their counterparts in partner states, typically drawing inspiration from initiatives inspired by Brazil's domestic experiences. This approach means that Brazilian technical cooperation lacks the thick middle layer of "development experts" that populate other countries' donor agencies and international organizations, as Brazil's providers hold expertise in their given technical field much more than in the transmission of those skills in foreign contexts. While this approach generates few knowledge-generating mechanisms and less institutional memory, it also reduces bureaucracy and some expenses, for instance the maintenance of offices and personnel abroad.

At the same time, during the Lula years Brazil expanded its humanitarian role abroad. Within the Ministry of External Relations, a separate division was created in 2004, the General Coordination of Humanitarian Cooperation and Fight against Hunger (CGFOME). The division was tasked with coordinating Brazil's humanitarian assistance, much of which focused on agricultural and nutritional issues via financial and grain donations to UN agencies and programs, as well as specific initiatives undertaken in partnership with other government divisions, such as the Ministries of Health, Defense, and Agriculture. From 2006 to 2015, Brazil channeled 
humanitarian assistance to 96 countries in Latin America, Africa, Asia, and the Middle East (Ministry of Foreign Affairs 2016).

There were some exceptions to this pattern of periodic missions, both in Mozambique and therefore part of broader efforts to foment stability in this post-conflict state: The first was a factory meant to produce medicine locally, especially anti-retrovirals for HIV/AIDS. The second was a triangular cooperation project, undertaken in collaboration with the JICA, to transform large swaths of Mozambique into a corridor for exportoriented production of commodities (Suyama and Pomeroy 2015). Both these projects ran into problems of scale and financing and, in the case of ProSavana, met resistance by local as well as Brazilian civil society actors. These examples have made some Brazilian diplomats and specialists form the implementing agencies reluctant to take on ambitious, costly projects abroad.

The most strategic initiatives in these settings have become labeled as "structuring projects" (projetos estruturantes), and they are meant to build individual and institutional capacity to catalyze sector-wide reform inspired by Brazilian policy models. For instance, Fiocruz has been engaged in the creation and expansion of national public health schools that draw inspiration not only on Brazil's own public health schools, but also on the SUS, its public health system, which is based on Brazil's constitutional right to universal access to free health care. Through these structuring projects, Brazil seems to offer state-led alternatives to models promoted by Western donors and major international organizations. However, in some instances they are implemented with little attention to local civil society, which contrasts to the very origins of those systems back in Brazil. For instance, the SUS itself resulted as much from grassroots activism during Brazil's redemocratization in the 1980 s as from government efforts. As a result, when such models are used as inspiration for post-conflict settings like Mozambique and Angola, they may run into difficulties resulting from the "political disembeddedness" of the cooperation projects, which do not take into account the role of local civil society (Abdenur and Marcondes 2016).

Brazil's peacebuilding has also included economic cooperation, including via trade and investments (particularly infrastructure), which are viewed as necessary for triggering growth in partner states and essential for post-conflict reconstruction. For instance, although starting from a relatively low base in absolute numbers, there were efforts under Lula to both intensify and diversify Brazil's commercial exchanges with African 
states. These flows were mostly comprised of Brazil exporting manufactures and semi-processed goods and importing from Africa commodities. In addition, there was an expansion of Brazilian investments in Africa, especially by large companies - either state-affiliated ones like the oil company Petrobras or the airplane manufacturer Embraer, or private ones like Odebrecht, Camargo Corrêa, and other Brazil-based multinationals specializing in infrastructure construction. The mining purchased major concessions and planned large investments around Africa. Some of these companies' investments were partially financed by the Brazilian National Development Bank (BNDES), which created special credit lines for export incentives and even opened a regional office in Johannesburg to help coordinate these ties (BNDES 2013).

Within Africa, Brazil has engaged most deeply, although sporadically, in Guinea-Bissau. Many of the strengths, and contradictions, of Brazilian peacebuilding are evident in this case. At the UN, Brazil has long acted on behalf of Guinea-Bissau, trying to call attention from the international community to the country's problems, which concern not just recurring political instability but also chronic underdevelopment. Even as Brazil was a very active participant in the creation of the UN peacebuilding architecture, including the Peacebuilding Commission (PBC), it continued to work via the UN and the CPLP to garner resources and political dedication to trying to solve Guinea-Bissau's instability and poverty. Once the PBC was established, Brazil assumed the leadership of the CountrySpecific Configuration for Guinea-Bissau, through which it has tried to mobilize political solutions, especially by helping to coordinate the role of regional states and ECOWAS in preventing further coups-d'état in Guinea-Bissau (Abdenur and Marcondes Neto 2014). After the April 2012 coup, Ambassador Antonio Patriota undertook fact-finding missions to the country, strengthened communications about Guinea-Bissau between the PBC and the UNSC (where Guinea-Bissau competes for attention with more severe crises), and was highly proactive in working with ECOWAS to prevent spillovers from the crisis (UN Secretary General Report on Peacebuilding in Guinea-Bissau 2015).

Brazil has also tried to implement bilateral cooperation efforts in Guinea-Bissau, ranging from the construction of a security forces training center to technical cooperation in areas like education and agriculture, particularly with a view to helping diversify the country's economy away from its narrow reliance on the cashew nut cash crop (Brazilian Agency for Cooperation 2012). Finally, Brazil has invested heavily in trying to boost 
Guinea-Bissau's electoral system and human rights institutions, but the recurrence of coups in Bissau attests to the limitations of Brazil's approach and, more broadly, of the efforts by the broader international community.

\section{International Conflict Mediation}

Brazil also tried to expand its role in international mediation, which historically had been largely limited to South America, for instance in the successful efforts to mediate a brief border conflict (the Cenepa War) between Ecuador and Peru in 1995. In the 2000s, Brazil became more willing to engage in international conflict mediation outside its own region. For instance, in 2007, Brazil was the only Latin American country to be invited to the Middle East peace conference in Annapolis, on the Palestine-Israel peace process. Yet the most visible and controversial such attempt involved a collaboration with Turkey and the USA to temper growing tensions surrounding Iran's nuclear program. These efforts culminated in a 2010 agreement signed by Iran, Brazil and Turkey, whereby Iran would send low-enriched uranium to Turkey in exchange for enriched fuel for Iran's nuclear research reactor (CFR 2010). The deal was not implemented for a variety of reasons, including the withdrawal of US support, and the outcome made Brazilian diplomats a bit more reluctant to engage in such high-level mediation attempts. However, the experience did not stop Brazil (under Dilma Rousseff) from working through IBSA in an attempt to mediate the intensifying conflict in Syria; in August 2011, the three countries sent ministerial delegations to Damascus and were met there by President Bashir al-Assad, who promised (in vain) that his regime would act to stop the escalation of violence (Ministry of Foreign Affairs 2011).

\section{Points of Tension}

However, Brazil's peacebuilding is also marked by some points of tension between its discourse and practice. For instance, to some analysts, Brazil's longstanding commitment to non-intervention seemed to come into contradiction with its participation in MINUSTAH, a Chapter VII mission (although the Brazilian government argued that only one chapter of Resolution 1542, which created the Multinational Interim Force, was based on Chapter VII, rather than the whole resolution; Fishel and Sáenz 2007). Another point over which Brazilian peacebuilding has been criticized is that of insufficient transparency and accountability 
of initiatives. Although IPEA, the government think tank, has been in charge of collecting data on different aspects of Brazil's South-South cooperation, the government institutions that are invited to open up their data do so voluntarily (IPEA 2011).

More broadly, the MRE in particular has been reluctant to adopt monitoring and evaluation practices because these are considered by some Brazilian cooperation specialists to have a heavily Western bent, especially when associated with the practices of donor countries and the Organisation for Economic Co-operation and Development (OECD). However, recognizing the need for more systematic planning that establishes benchmarks for both process and outcome-based evaluations, ABC in 2016 began considering the possibility of developing "homegrown" M\&E practices. It is worth noting that the public institutions from which Brazil's SouthSouth cooperation experts are drawn, such as Fiocruz and Embrapa, have robust mechanisms for $M \& E$ that are applied to projects domestically, and that these toolboxes have not been implemented abroad partly due to the low institutionalization of Brazilian peacebuilding, but also due to political resistance. ${ }^{10}$ At any rate, part of objective of this technical cooperation is political-the maintenance of good diplomatic relations, an element that is not readily captured by traditional M\&E processes.

Also on the flip side, Brazilian arms companies like Taurus also benefitted from expanding African markets (and indirectly, from African conflicts and instability) to boost their sales of arms and military equipment, including some, such as cluster bombs, that had been banned under UN regimes. In 2013, Brazilian exports transferred some USD\$10 million in small arms and accessories alone to other countries (Small Arms Survey 2014). As with other major arms-exporting countries, these transfers sometimes undermine Brazil's peacebuilding credentials abroad.

\section{The Retraction in Brazil's Peacebuilding}

Despite their close political relationship during Lula's presidency, the transition from Lula to his former chief of staff, Dilma Rousseff, saw a noticeable shift in foreign policy. Rousseff seemed to take little interest in issues of foreign policy, aside from commercial and investment relations, and her presidential diplomacy reflected this relative lack of attention (in her five and a half years of presidency, she only visited three African states, for instance-South Africa, Angola, and Mozambique). There were also strained relations between the presidency and the MRE, 
with abrupt switches of foreign ministers on two occasions. Although Brazilian diplomats (who are overwhelmingly career professionals) provided some continuity to political and cooperation efforts, for instance Brazil's commitment to the BRICS, there was a considerable retraction in high-visibility engagement, both in South-South Cooperation and in relations with the North. As one Brazilian diplomat remarked in 2015 about the country's role at the UN, "We learned how to be agenda makers. Now maybe we are rolling back that role."1l Brazil's global role was also complicated by damaged US-Brazilian relations after Wikileaks documents showed widespread cyberespionage by the US government against Brazilian companies and political leaders, including the president herself.

This foreign policy shift and its economic context-a combination of falling prices in key commodities and ineffective policies-have had concrete repercussions for Brazil's peacebuilding efforts. By 2014, the Brazilian government faced serious economic challenges, as GDP growth dropped from a peak of 7.5 in 2010 to below $1 \%$ in 2014. As a recession ensued, wide budget cuts were made, including to the MRE. These cuts affected not only Brazil's South-South development cooperation at $\mathrm{ABC}$, but also the day-to-day operation of its embassies and other diplomatic representations abroad. According to one source, the budget of the CGFOME dropped precipitously from 2010 to 2014.

When the Brazilian Congress first voted to impeach President Rousseff, in spring 2016, Vice President Michel Temer became an interim president and appointed José Serra, a São Paulo politician and former presidential candidate from the opposition party PSDB, as a foreign minister. In his inaugural speech, Serra indicated that the Temer government would stress different priorities than the two preceding Workers Party-led governments, notably by deemphasizing the role of South-South cooperation and seeking to deepen ties to the USA and Western Europe. Temer's government indicated that it wished to tone down the anti-Western rhetoric of both Lula and Rousseff and to deepen ties to the OECD and to northern countries (Ministry of Foreign Affairs 2016). Discussions began within Brazil about phasing out the country's role in MINUSTAH, although some have noted that such a retraction would deeply impact Brazil's visibility in international peacekeeping unless troop contributions to other UN missions were made. However, the discussions have not yet yielded a concrete plan. At the same time, some restructuring within the MRE has generated new sources of uncertainty. In August 2016, after the presidential impeachment had been completed, the government announced that the 
CGFOME had been permanently closed. Although its humanitarian assistance initiatives were reallocated to $\mathrm{ABC}$ and the Social Policy division, this restructuring signaled the Temer government's non-prioritization of Brazil's role in humanitarian action (Valente 2016).

Although it is too soon to say what the mid- to long-term effects of the new government's reorientation will be, deep uncertainty surrounds Brazil's future role in peacebuilding, especially outside of the UN. Brazil's engagement with peacebuilding follows an arc-a steep surge followed by a seemingly, equally steep decline in its engagement abroad. This variation raises broader questions about how vulnerable the rising power's newfound roles in peacebuilding are to political winds and economic downturns. The low degree of institutionalization and questionable commitment of the state to these recent initiatives make their sustainability unclear.

\section{Conclusion}

In its peacebuilding engagement, which peaked in the 2000s, Brazil pursued both bilateral and multilateral avenues. However, in comparison with other large rising powers like China, Russia, Indonesia, India, and Turkey, much of Brazil's engagement has taken place through multilateral institutionsnot only the UN, but also informal coalitions such as the G20, BRICS, and IBSA. This option reflects the central role that multilateralism has played in Brazilian diplomacy, including the belief that collective, UN-sanctioned initiatives tend to be the most legitimate course of action.

Despite the discourse of demand-driven initiatives, Brazil's peacebuilding is motivated by a combination of interests and identity. While the country's history, including its constitutional landmarks, have established a set of principles that serve as more or less stable guidelines for its foreign policy, they are not always applied in a uniform or consistent manner. Under Lula, Brazil's aspiration to accelerate the transition of the international system toward a more multipolar configuration no doubt influenced some of its peacebuilding engagements. A related objective - a permanent seat at the UNSC-was also among the drivers behind Brazil's expanding engagement with peacebuilding. In turn, these aspirations raised the expectations that other actors in the international community have about Brazil's role in peace and security, both quantitatively (for instance, in terms of financial or troop contributions) but also qualitatively, through innovative approaches to promoting peace.

Brazil has consistently argued in favor of a less militarized approach to international security issues, and most of its peacebuilding efforts rely more 
heavily on mediation, investment in socioeconomic development (not only through social policy and job generation, but also via infrastructure development), and coordination between national and regional actors.

One persistent question, however, concerns the sustainability of these initiatives. Will there be a resurgence in Brazilian peacebuilding? Within the UN, it is likely that Brazil's political commitment to the PBA, which has been deeply entrenched both in Brasilia and at the mission in New York, will continue. Outside of the UN, the possibility of another surge in Brazilian peacebuilding is constrained not only by the dual political and economic crisis, but also by the "spread too thin" character of Brazil's engagement during the 2000s. This overextension is particularly evident in the country's South-South development cooperation portfolio, with many projects indefinitely suspended in 2016 due to budget cuts. Combined with low institutionalization, as reflected in the lack of a dedicated legal framework and career path specializing in development cooperation within the MRE, the funding gap leads to lapses in institutional learning and feedback mechanisms that would enable improvements, such as in project planning and accountability.

Although Brazil's expanded peacekeeping role has been highly visible, thanks to its participation in MINUSTAH and MONUSCO, the way that Brazil links peacekeeping and peacebuilding initiatives differs from the approaches of the other rising powers. For instance, whereas India sees development and peacebuilding as deeply intertwined, and whereas Turkey links peacebuilding with humanitarian and peacemaking efforts, for Brazil there is a clearer (but by no means absolute) distinction between peacekeeping and peacebuilding. Brazil does embrace the distinction between those two spheres made in UN circles, but these two dimensions are more closely linked in Brazilian practice than in Western efforts. This is because Brazil views peacebuilding as a key corrective to conventional approaches to peacekeeping, especially the heavy focus on security and military-dominated initiatives. By linking civilian peacebuilding alongside peacekeeping operations, as was done in Haiti through the partnership with Viva Rio, Brazil hopes to ensure that peacekeeping missions not only meet the everyday security needs of the local population, but also helps to ensure its economic and social well-being. Brazil's main contribution, therefore, is not to enhance the Western approach to peacebuilding, but rather to use peacebuilding in order to help rebalance Western approaches in a less securitized direction. However, in order to push for deeper transformation, Brazil needs to make its own peacebuilding more sustainable, coherent, and accountable. 


\section{Notes}

1. Interview with Prof. Tania Manzur, July 2015, Brasilia.

2. Interview with Prof. Tania Manzur, July 2015, Brasilia.

3. Brazil entered World Wars I and II only after its ships were attacked.

4. As of September 2016, UNASUR comprises 12 South American countries: Argentina, Bolivia, Brazil, Chile, Colombia, Ecuador, Guyana, Paraguay, Peru, Uruguay, Suriname, and Venezuela.

5. Interview with Brazilian diplomat in Brasília, November 2015.

6. CT Call personal interview with Brazilian diplomat who had worked at the mission to the United Nations and requested anonymity, August 2015, Brasilia.

7. CT Call personal interview with Brazilian diplomat who had worked at the mission to the United Nations and requested anonymity, August 2015, Brasilia.

8. CT Call personal interview with Brazilian diplomat who requested anonymity, August 2015, Brasilia.

9. CT Call personal interview with Leopoldo Paz, August 2015, Brasilia.

10. Interview with Fiocruz specialist, Rio de Janeiro, October 2016.

11. CT Call personal interview with Brazilian diplomat who requested anonymity, August 2015, Brasilia.

\section{REFERENCES}

Abdenur, Adriana, and Danilo Marcondes. 2016. Democratization by Association? Brazil's Social Policy Cooperation in Africa. Cambridge Review of International Affairs: 1-19. doi:10.1080/09557571.2015.1118996.

Abdenur, Adriana, and Danilo Marcondes Neto. 2014. Rising Powers and the Security-Development Nexus: Brazil's Engagement with Guinea-Bissau. Journal of Peacebuilding \& Development 9(2): 1-16.

Biato, Marcel. 1999. O processo de paz Peru-Equador. Parcerias Estratégicas 6: 247-247.

Brazilian Development Bank. 2013. BNDES Inaugurates its Representative Office in Africa. http://www.bndes.gov.br/SiteBNDES/bndes/bndes_en/Institucional/ Press/Noticias/2013/20131206_africa.html

BRICS. 2014. Agreement on the New Development Bank. http://ndb.int/ charter.php

Constituicao. 1934. Constitution of the Republic of the United States of Brazil. 16 July 1934.

Council on Foreign Relations. 2010. Joint Declaration by Iran, Turkey and Brazil on Nuclear Fuel. http://www.cfr.org/brazil/joint-declaration-iran-turkeybrazil-nuclear-fuel-may-2010/p22140 
de Abreu, Fernando Jose Marroni. 2013. Speech before the Chamber of Deputies. Brasilia.

de Quieroz, João Marcelo Galvão. 2016. ABACC: Os Primeiros 25 Anos. Cadernos de Politica Exterior 2/3: 45-64.

Fishel, John T., and Andrés Sáenz. 2007. Capacity-Building for Peacekeeping: The Case of Haiti. Potomac Books.

Hirst, Monica. 2010. O Haiti e os desafios de uma reconstrução sustentável—um olhar sul-americano. Revista Politica External 10(1): 103-111.

IPEA. 2011. Cooperação Brasileira para o Desenvolvimento Internacional (Cobradi). Brasília: Instituto de Pesquisa Econômica e Aplicada.

Ministry of Foreign Affairs. 2011. Statement to the Press from IBSA about Consultations Held in Syria-Damascus. http://www.itamaraty.gov.br/en/pressreleases/14334-declaracao-a-imprensa-do-ibas-sobre-consultas-mantidas-nasiria-2

- 2014. O Brasil e os dez anos da MINUSTAH. Blog do Itamaraty. http:// blog.itamaraty.gov.br/82-o-brasil-e-os-dez-anos-da-minustah

- 2016. Histórico da cooperação humanitária brasileira. Brazilia. http:// www.itamaraty.gov.br/pt-BR/notas-a-imprensa/2-sem-categoria/13229historico-da-cooperacao-humanitaria-brasileira

Muller, Markus-Michael. 2016. Entangled Pacifications: Peacekeeping, Counterinsurgency and Policing in Port-au-Prince and Rio de Janeiro. In The Global Making of Policing: Postcolonial Perspectives, ed. Jana Honke and Markus-Michael Muller. London: Routledge.

Patriota, Antonio. 2011. Speech on the occasion of the open debate convened by Brazil as Chair of the UN Security Council. New York.

Patriota, Antonio Aguiar, and Héctor Marcos Timerman. 2011. Brasil e Argentina, Cooperação Nuclear. O Estado de São Paulo. http://www.itamaraty.gov.br/ pt-BR/discursos-artigos-e-entrevistas-categoria/ministro-das-relacoesexteriores-artigos/4598-brasil-e-argentina-cooperacao-nuclear-o-estado-de-spaulo-06-7-2011

Peixoto, Fabricia. 2010. Em oito anos, Lula visitou 85 países em bisca de parceiros comerciais e políticos. BBC Brasil. http://www.bbc.com/portuguese/noti cias/2010/12/101227_eralula_diversificacao.shtml

Pinheiro, Leticia. 2007. Ao vencedor, as batatas: o reconhecimento da independência de Angola. Estudos Históricos 39: 83-120.

Ribeiro, Darcy. 1995. O Povo Brasileiro. Rio de Janeiro: Companhia das Letras.

Santos, Rita, and Teresa Almeida Cravo. 2014. Brazil's Rising Profile in United Nations Peacekeeping Operations Since the End of the Cold War. Norwegian Center for Conflict Resolution (NOREF) Report. https://www.ciaonet.org/ attachments /24875/uploads

Small Arms Survey. 2014. Exporter. http://www.smallarmssurvey.org/weaponsand-markets/transfers/exporters.html 
Suyama, Bianca, and Melissa Pomeroy. 2015. Picking and Choosing: Contributions of Brazilian Cooperation to More Horizontal Post-2015 Partnerships. São Paulo: Articulação Sul.

United Nations Office on Drugs and Crime. 2013. Global Study on Homicide: Trends, Contexts, Data. Vienna: United Nations Office on Drugs and Crime. https://www.unodc.org/documents/gsh/pdfs/2014_GLOBAL_ HOMICIDE_BOOK_web.pdf.

United Nations Security Council. 2011. Statement by the President of the Security Council. http://www.un.org/ga/search/view_doc.asp?symbol=S/PRST/2011/4 Valente, Gabriel. 2016. Itamaraty extingue departamento de combate à fome. O Globo. http://oglobo.globo.com/brasil/itamaraty-extingue-departamentode-combate-fome-20101655

Vigevani, Tulio, and Gabriel Cepaluni. 2012. Brazilian Foreign Policy in Changing Times: The Quest for Autonomy from Sarney to Lula. Lanham, Maryland: Lexington Books.

Viva Rio. Gingando Pela Paz. 2015. http://vivario.org.br/viva-rio-no-haiti/ centro-comunitario-kay-nou/gingando-pela-paz/

Adriana Erthal Abdenur is Fellow at the Instituto Igarapé and Senior Postdoctoral Researcher at the Fundação Getúlio Vargas, Rio de Janeiro.

Charles T. "Chuck" Call is Associate Professor of the International Peace and Conflict Resolution School of International Service, American University, Washington DC.

Open Access This chapter is licensed under the terms of the Creative Commons Attribution 4.0 International License (http://creativecommons.org/licenses/ by $/ 4.0 /)$, which permits use, sharing, adaptation, distribution and reproduction in any medium or format, as long as you give appropriate credit to the original author(s) and the source, provide a link to the Creative Commons license and indicate if changes were made.

The images or other third party material in this chapter are included in the chapter's Creative Commons license, unless indicated otherwise in a credit line to the material. If material is not included in the chapter's Creative Commons license and your intended use is not permitted by statutory regulation or exceeds the permitted use, you will need to obtain permission directly from the copyright holder.

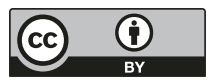

